\title{
"Smart Service" as an innovative system of service for mining companies in Kuzbass
}

\author{
Lyudmila Samorodova ${ }^{1}$, Larisa Shut'ko ${ }^{1}$, Yulia Yakunina $^{1}$, and Oleg Lyubimov ${ }^{2 *}$ \\ ${ }^{1}$ KuzSTU, Department of economics, 650000 Kemerovo, Russia \\ ${ }^{2}$ KuzSTU, Department of information and automated manufacturing systems, 650000 Kemerovo, \\ Russia
}

\begin{abstract}
The article deals with the issues related to the introduction of "smart service" as an innovative system of equipment service in the business system and "Life-Cycle Management" (LCM) by mining equipment manufacturers. Based on the analysis of the competitive environment an overview description of the competitive environment in the field of equipment sales for surface and underground mining as well as for maintenance and repair of mining machinery for surface mining is presented. The article describes the results of the survey of top managers from company-clients of the company "Joy Global" to identify the demand characteristics of mining companies in using the "Life-Cycle Management" program ranking them in order of priority. To justify the viability of the corporate service package taking into account the individual needs of mining companies within the system "smart service" the contingency of service package and their demand by mining enterprises is used.
\end{abstract}

\section{Introduction}

In recent years the global coal industry has been going through a number of problems. Reduced demand for coal leads to lower production volumes which, in turn, affects the companies providing the equipment and technologies for this industry.

Despite the downturn, the mining industry of Kuzbass is still one of the important areas of mutually beneficial cooperation between multinational and national mining companies in the region. It results in the formation of their investment relations and expansion of industrial activity including maintanance service [1-2].

\section{Material and method}

Multinational corporations presented in the mining industry of Kuzbass are mostly sellers of high quality mining equipment. Direct investments among international companies in the field of coal production and exports in the region are provided by only offshore company "Arcelor Mittal" (see Table 1). Many companies operating in the market of mining equipment and support service, feeling the pressure of the global and regional economies,

* Corresponding author: oleglyub@gmail.com 
begin to take steps to differentiate their services, rise to a new management level of maintenance service, which is one of the world trends in modern economy [3-7]. The growth and diversity of services, carefully developed service systems that meet the most challenging requirements of consumers, help them to enter new regional and industrial markets [8-10].

Table 1. Activities of multinational corporations in Kuzbass

\begin{tabular}{|c|c|c|}
\hline $\begin{array}{c}\text { Multinational corporations operating } \\
\text { in Kuzbass }\end{array}$ & Area of activity & $\begin{array}{l}\text { Area of interest in } \\
\text { Kuzbass economy }\end{array}$ \\
\hline “Arcelor Mittal" (Cyprus) & $\begin{array}{l}\text { Coal mining and } \\
\text { processing }\end{array}$ & Coal mining \\
\hline $\begin{array}{c}\text { "Joy Global Inc." (USA) } \\
\text { "Komatsu" (Japan) } \\
\text { "Caterpillar" (USA) } \\
\text { "Taiyuan Heavy Industry Co." (China) } \\
\text { "Liebherr" (Germany) } \\
\text { "Ferrit" (Czech Republic) }\end{array}$ & $\begin{array}{l}\text { Manufacturing of } \\
\text { industrial and } \\
\text { mining equipment }\end{array}$ & $\begin{array}{c}\text { Selling of mining } \\
\text { equipment } \\
\text { Organization of service } \\
\text { centers }\end{array}$ \\
\hline
\end{tabular}

The analysis of the competitive environment in the Kuzbass market of sales, maintenance and repair of mining equipment shows that the main competitors are:

- the sales of mining equipment for open pit mining - Caterpillar (USA), Inc. "URALMASHZAVOD" (Russia), JSC "IZ-KARTEKS named after P.G. Korobkov" (Russia), Taiyuan Heavy Industry Co. (China); Liebherr (Germany), "Joy Global Inc."(the USA);

- the sales of mining equipment for underground mining and support service providing - the company "Ferrit" (Czech Republic), which official representative in Kuzbass is JSC "Sibtransservis" [11];

- the support service for surface mining - Belovo Energoremontnaya plant (Russia); "Siberia Service" (Russia); "Pride +" (Russia); Inc. "Anzheromash" (Russia).

The company "Joy Global Inc." is a leader in the mining industry [12-13]. The company's motto is "We are there where coal is mined." "Joy Global Inc." has long and strong relations with Russian coal industry and a significant number of regional offices which were merged into one holding company JSC "Joy Global" in 2013.

The main activity of this company in Kuzbass is the maintenance of mining equipment in surface and underground mining operations. Its long-range strategy is the expansion of services in the field of mining equipment support on the basis of the service center established in Prokopyevsk in 2015 and the development of innovative service technology "smart service". The analysis of international experience shows that the system "smart service" is integrated into the "Joy" business system (JBS), under which the general principles of program "Life-Cycle Management" (LCM) in any region of the world are strictly regulated through direct service network [14].

Expanding the scope of services "Joy Global Inc." offers solutions for the life cycle management of equipment by building partnership relations with the customers to help them to maximize productivity by optimizing the equipment performance throughout its life in the mine. Direct support service, working at enterprises and regional service centers, provide maintenance and repair along with high-quality spare parts meeting the unique needs of each mining enterprise. "Joy Global Inc." teams work in tandem with the staff of mining enterprises and meet the operational and production requirements, focusing on lowering the cost per ton, increasing production, and supporting a zero harm environment throughout the life cycle of equipment [15].

In 2016 the authors surveyed the top-managers of 12 largest mining company-clients of "Joy Global". The purpose of the survey was to determine the nessecaty degree for the 
enterprises to use the system "Life-Cycle Management" taking into account the innovation made by "Joy Global" - "smart service", i.e. the system of "the most well-organized service."

\section{Results and discussion}

In the survey of the top managerial groups the current needs of the mining enterprises of Kuzbass were defined and ranked according to their importance. The results are shown in Fig. 1-2.

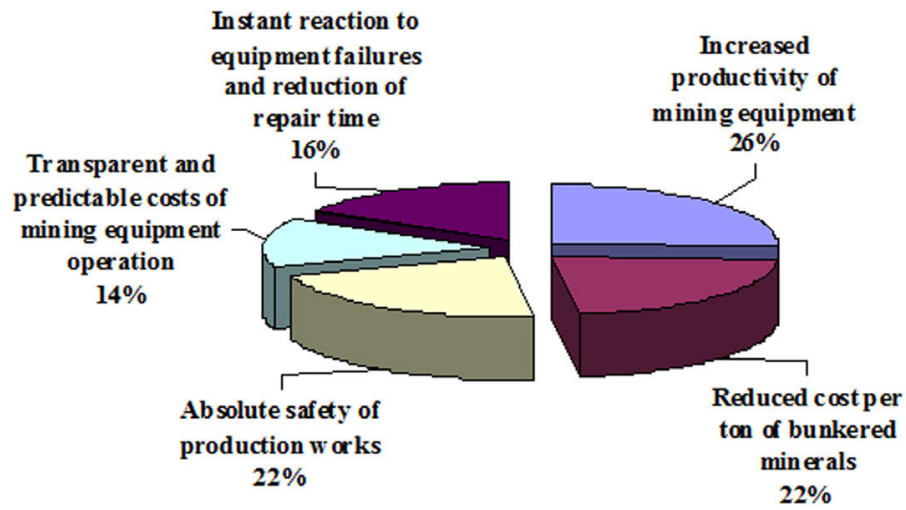

Fig. 1. The importance of the basic needs of the mining enterprises in Kuzbass

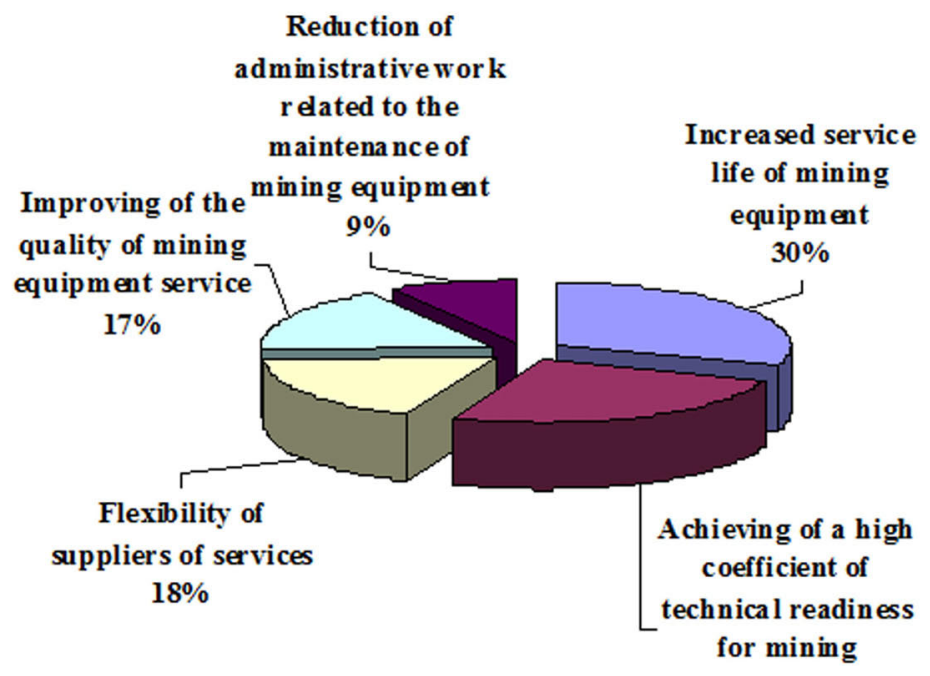

Fig. 2. The importance of the secondary needs of the mining enterprises in Kuzbass

As the basic needs in descending order of importance for enterprises were the following:

- an increase in productivity of mining equipment;

- reducing the cost per ton of mined mineral resource;

- absolute safety of prodution works;

- instant response to the equipment failures and reduction of repair time;

- transparent and predictable operating costs of the equipment. 
The secondary needs of the top managers were the following:

- increased service life of mining equipment;

- Achieving of a high coefficient of technical readiness for mining;

- flexiblility of service providers;

- improving the quality of mining equipment service;

- reduction of administrative work related to the maintenance of mining equipment.

The survey showed that the provision of qualitative and in time services, taking into account the diversity of the customers and their needs, requires the formation of a broad set of service offers designed to achieve maximum performance and productivity of mining equipment. As being recommended the following service options to meet the individual reqiements of each regional customer including service package were offered:

- spare parts and consumables;

- assembly and machine rebuilding;

- service program of sharing components;

- maintenance of equipment in operation;

- repair in service center.

Based on the technical base, customers can choose the most effective, in terms of technical and economic indicators, service package for the equipment.

Using the survey results, by the methods of cluster analysis [16] dendogrammies were built. They define contingency of service packages and the optimal sequence of their demand by the mining enterprises.

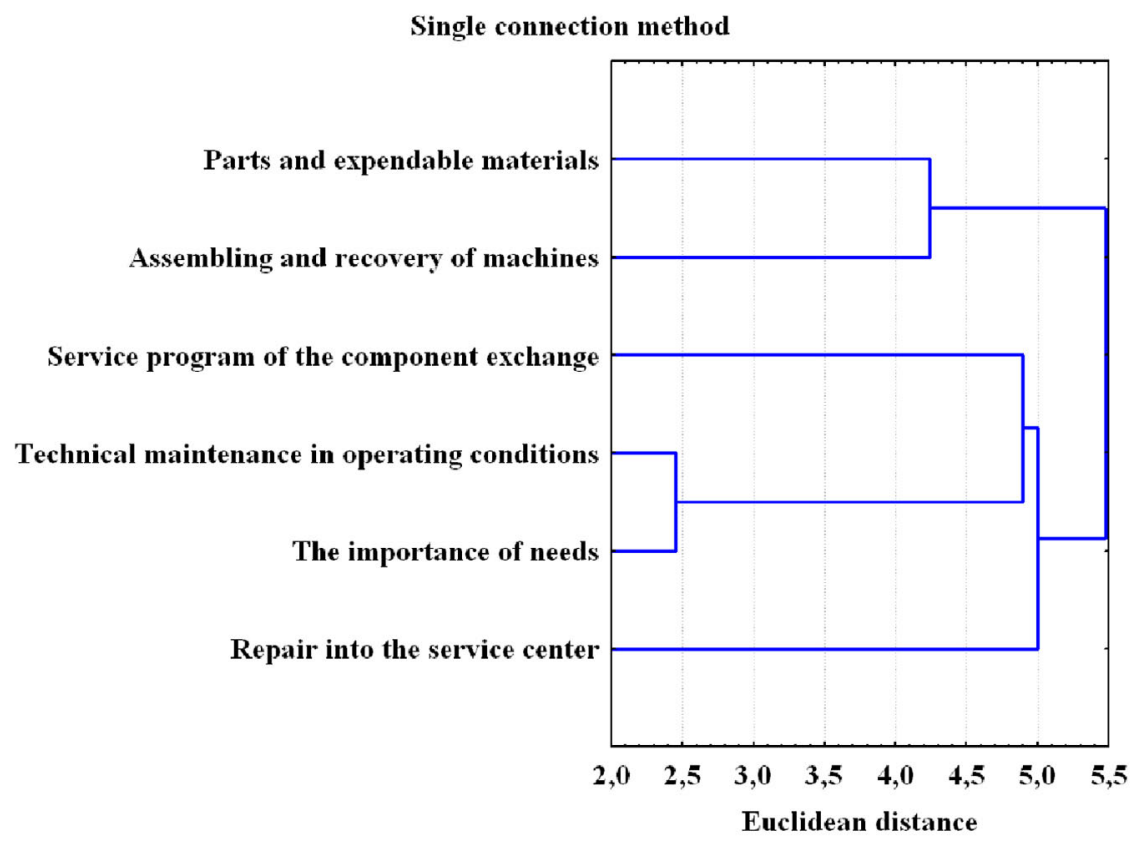

Fig. 3. The contingency service packages defined by the cluster analysis

Having processed the data on the selection of a service package the results showed the following:

1. Decisions about the maintenance of equipment in operation directly depends on the current needs of the mining enterprise.

2. Service package, providing regulated replacement of the parts, is most likely to be extanded to the package of assembly and reduilding of equipment in the service center. 
3. In future, these packages can be supplemented by the service program of component exchange and, as a result, direct equipment repair in the service center.

\section{Conclusion}

Thus, the correlation analysis carried out on the basis of survey showed that today there is a real need for the customers of "Joy Global" in business cooperation and contracts based on the "Life-Cycle Management" program, using the innovative technology "smart service". This technology provides the possibility to control every equipment unit in operation from the surface. It helps to monitor continuously every movement, every change in the operating parameters, allowing to control not only the machinery, mechanisms, eqipment, but human activity, to have a clear idea of what is happening at the moment in each division of underground production.

Investing in the structure of the region, the company "Joy Global Inc" ensures a steady demand for its products. Kuzbass needs in effective, high-tech industries that can provide jobs for qualified personnel, improve their skills. Even today, an American company, based on the service center, organized the production of self-propelled electric cars JOY10SC32$36 \mathrm{~V}$ intended for "the use in high-aggressive environments." The first copy of the product was introduced in early June in 2016 at the XXIII-th International Exhibition "Russian Coal and Mining". In the long term the service center "Joy Global Inc." will serve the territory not only in Russia, but also in neighboring countries, including Kazakhstan. Stable industrial region is always attractive for investors, including foreign ones. The processes are interrelated, and the understanding of this ensures the sustainable development of the region and benefits for the investors.

In general, to have sustainable competitive position in the regional markets in modern conditions for the manufacturer of mining equipment it is necessary not only to produce high-tech products, but also to ensure its entire life cycle, which results in the development of "smart service" as an innovative service system for mining companies in Kuzbass.

\section{References}

1. V. Fomychov, Min. of Min. Depos., 10, 89 (2016)

2. L. Samorodova, Yu. Yakunina, O. Lyubimov, Adv. in Eng. Res., 92, 50 (2016)

3. M. Chetveryk, O. Mishina, Min. of Min. Depos., 8, 519 (2014)

4. M. Stupnik, V. Kalinichenko, V. Kolosov, I. Bah, V. Pozdniakov, Min. of Min. Depos., 8, 199 (2014)

5. C. Hall, C. Cleveland, EROI: definition, history and future implications (ASPO US Conference, Denver, 2005)

6. R. Heinberg, J. Mander, Searching for a miracle: Net energy limits \& the fate of industrial society (Post Carbon Institute, Santa Rosa, CA, 2009)

7. V. Krasnik, Min. of Min. Depos., 7, 93 (2013).

8. M.A. Tyulenev, S.A. Zhironkin, E.A. Garina, Int. J. of Mining and Mineral Engineering, 7:4, 363 (2016)

9. M. Tyulenev, E. Garina, A. Khoreshok, O. Litvin, Y. Litvin, E .Maliukhina, IOP Conf. Ser.: Earth Environ. Sci., 50, 012035 (2017)

10. S. A. Zhironkin, K. A. Kolotov, A. E. Genin, F. V. Agafonov, S. A. Kovalevsky, IOP Conf. Ser.: Earth Environ. Sci., 50, 012011 (2017)

11. About company Ferrit, URL: http://www.ferrit.cz/en/about-company/ 
12. P\&H and Joy aligned under Joy Global name, URL: http://www.canadianminingjournal.com/features/p-h-and-joy-aligned-under-joy-global-name/

13. MINExpo 2016 Review, URL: https://www.worldcoal.com/mining/28122016/minexpo-2016-review-earthmoving/

14. Joy Global Achieves 100\% ROI in the First 9 Months, URL: https:// www.meridium.com/clients/joy-global-inc

15. Joy Global Delivers the Smart, Connected Mine, URL: https:// industrialiot.com/2016/03/industrial-internet-of-things-mining/

16. M. Aldenderfer, R. Blashfild, Cluster Analysis (Second Printing, 1985) 